\title{
Adult Multiloculated Cystic Nephroma: A Case Report
}

\author{
Erişkin Tip Multiloküle Kistik Nefroma: Olgu Sunumu
}

\author{
Orkun Batmaz $\odot$, Murat Uçar $\odot$, Erdem Aktaş $\oplus$, Bahar Akkaya $\oplus$, i̇smail Türker Köksal $\odot$
}

Olgu Sunumu Case Report

Alındığı tarih: 09.05.2019

Kabul tarihi: 31.05.2019 Online Yayın tarihi: 28.03.2020

Orkun Batmaz Tepecik Training and Research Hospital, Department of Urology, Izmir - Turkey

orkun.batmaz@hotmail.com ORCID: 0000-0003-3924-2325

M. Uçar 0000-0001-6977-7430 E. Aktaş 0000-0002-8268-6653

B. Akkaya 0000-0001-8054-294X

i.T. Köksal 0000-0002-7606-1200 Department of Urology Akdeniz University, Antalya, Turkey

Cite as: Batmaz O, Uçar M, Aktaş E, Akkaya B Köksal iT. Adult multiloculated cystic nephroma: A case report. Tepecik Eğit. ve Araşt. Hast. Dergisi. 2020;30(1):84-7.

\section{ABSTRACT}

A 71-year old women who underwent radical nephrectomy due to left renal mass is presented. The histopathological examination was reported as adult cystic nephroma, which is very seldom benign tumour of the kidney. The epidemiology, differential diagnosis, histopathological features, and treatment options are discussed.

Keywords: Cystic Nephroma, Benign, Kidney, Pathology

Öz

Sol böbrek kitlesi nedeniyle radikal nefrektomi yaplan 71 yaşındaki kadın hastada erişkin tip multiloküle kistik nefroma olgusu sunulmuştur. Erişkin multiloküle kistik nefroma oldukça nadir görülen benign bir tümördür. Olgumuzda hastalığın epidemiyolojisi, histopatolojik özellikleri ve tedavi seçenekleri tartışılmıştır.

Anahtar kelimeler: Kistik Nefroma, Benign, Böbrek, Patoloji

\section{INTRODUCTION}

Multilocular cystic nephroma (MCN) is a rare benign lesion of the kidney which usually presents as a unilateral multicystic renal mass without solid elements and more often seen in bimodal age distrubition and adult onset form especially in postmeonopausal women. It was first described in 1892 as cystic adenoma of the kidney. Preoperative diagnosis of $\mathrm{MCN}$ is difficult and surgery is recommended to exclude malignant cystic lesions of kidney. However, partial removal of the mass can be an option depending on the site and size of the lesion. In this case, we are presenting a 71-yearold woman with MCN treated succesfully with total nephrectomy.

\section{CASE REPORT}

A 71-year-old woman was admitted to our urology department with a mass in her left kidney. She was investigated for the presence of resistant hypertension in nephrology outpatient clinic. Her systolic, and diastolic blood pressures at rest were $170 \mathrm{mmHg}$ and $100 \mathrm{mmHg}$, respectively. She was using irbesartan $300 \mathrm{mg}$ and propramia, atrial fibrillation and were using rosuvastatin $20 \mathrm{mg}$, furosemide $40 \mathrm{mg}$ and apixaban $5 \mathrm{mg}$ per day. Her creatinine $(1.07 \mathrm{mg} / \mathrm{dL})$, GFR: $(51 \mathrm{~mL} /$ $\left.\mathrm{min} / 1.73 \mathrm{~m}^{2}\right)$ and BUN (22.67 mg/dL) levels were as indicated. She had not any flank pain, hematuria or dysuria, history of smoking and family history of renal carcinoma. nolol $50 \mathrm{mg}$. She also had hyperlipide-

(c) Telif hakkı T.C. Sağılık Bakanlığı İmir Tepecik Eğit. ve Araşt. Hastanesi. Logos Tıp Yayıncılık tarafindan yayınlanmaktadı. Bu dergide yayınlanan bütün makaleler Creative Commons Atff-GayriTicari 4.0 Uluslararası Lisansı ile lisanslanmıştır.

(C) Copyright Association of Publication of the T.C. Ministry of Health İmir Tepecik Education and Research Hospital. This journal published by Logos Medical Publishing. Licenced by Creative Commons Attribution-NonCommercial 4.0 International (CC BY-NC 4.0) 
In her abdominal ultrasonography, there was a multicystic mass in her lower pole of the left kidney resembling hydatid cyst and cystic renal cell carcinoma. There was a multicystic mass the largest one having a diameter of $5.5 \mathrm{~cm}$. There was no obvious vascular signaling in the septae between the cysts in Doppler US scan which looked like type 3 hydatic cysts. However, a stone with $1.5 \mathrm{~cm}$ diameter in the middle calyx of left kidney and detorioration of the collection system. After observing this sonographic finding we decided to perform computerized tomography; and 104x86 mm-multicystic mass with multiple contrasted septae considered as cystic renal cell carcinoma was observed (Figure 1).

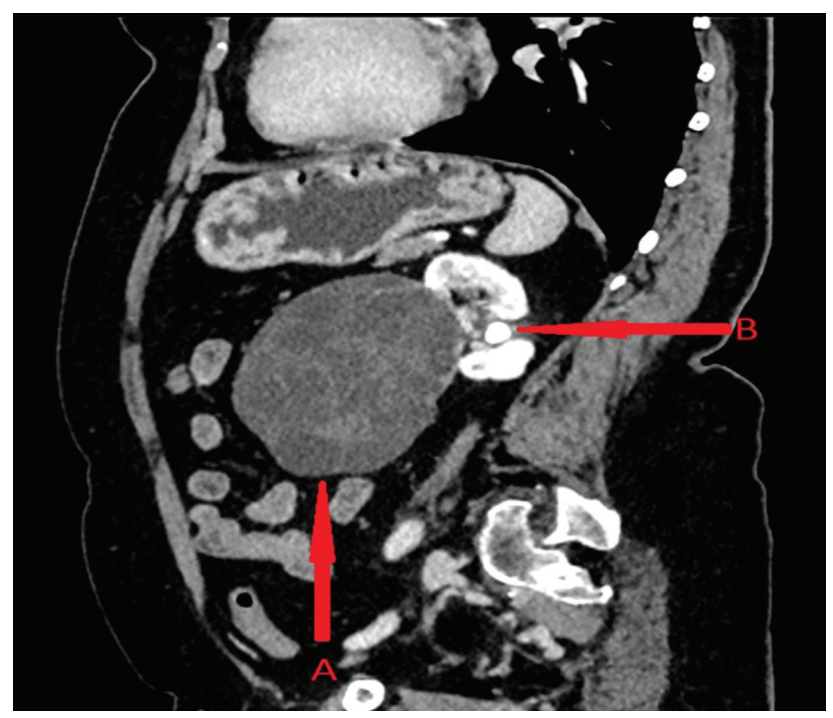

Figure 1.

Echinococcus granulosus IgG was not detected These findings forced us to perform renal exploration. We reached to the left kidney transperitonally and palpated the cystic mass in the lower pole of the kidney. There was no invasion into the adjacent tissues. We found one renal artery and vein without any collateral vasculature. We decided to perform left radical nephrectomy. Operation was performed without complication such as bleeding or injuring the adjacent viscera.

Oliguria/anuria, acute impairment of renal functions or anemia did not develop. After the fourth day of the operation we discharged the patient.

\section{DISCUSSION}

MCN is a very rarely seen benign entity characterized by multiple septations composed of differentiated tissue without blastemal elements slow-growing mesenchymal and epithelial neoplasm of kidney and there are more than 200 cases reported in the literature to the best of our knowledge ${ }^{(1)}$. Bimodal age distribution is often seen, accordingly it is mostly seen in children younger than 2 years and in the middle age (40-69 years) adults (male-to-female children ratio, 3:1 and adult female-to-male ratio, 9:1) (2). Pediatric cystic nephroma is a distinct entity. The presence of immature nephroblastic elements excludes the diagnosis of pediatric cystic nephroma and indicates partially differentiated cystic nephroblastoma ${ }^{(3)}$. Keeping in mind the age, clinical presentation and radiological appearance, cystic partially differentiated Wilm's tumour is a possibility. Since MCN has a benign behaviour it must be differentiated from focal cystic neoplastic lesions, including Cystic Partially Differentiated Nephroblastoma (CPDN), which has a low but distinct capability for local recurrence, differentiates from Wilm's tumour with cystic change. Segmental form of unilateral renal dysplasia also needs to be considered in the clinical and radiological differential diagnosis ${ }^{(4)}$.

Adults present with nonspecific signs and symptoms, including abdominal pain, hypertension, and urinary tract infection. Microscopic or gross hematuria can occur at all ages ${ }^{(5)}$. Our patient was a 71 year-old female presented to us with an incidental renal mass. Radiologically, MCN usually presents as a solitary, centrally located, approximately 6-cm tumor consisting of small noncommunicating small cysts ${ }^{(6)}$. Ultrasonography is usually performed as s first-line diagnostic tool and commonly seen in contrast -enhanced CT as a unilateral mass with irregular cysts containinng watery fluid and septae of variable thickness ${ }^{(7)}$. Sometimes, extension into the renal pelvis may be seen, which results in hydronephrosis and hemorrhage and usually resembled as category 
III Bosniak classification ${ }^{(8-9)}$. In time, CT became the primary imaging technique for evaluation of $\mathrm{MCN}$ but unfortunately can not be used to certainly differantiate other cystic renal masses like renal hydatic cyst and cystic renal cell carcinoma ${ }^{(10)}$. However, number of cases can encourage the performing percutaneous biopsy before surgery or frozen-biopsy intraoperatively and has the potential to avoid a significant number of major surgical procedures ${ }^{(11)}$.

In renal ultrasonography there was a multicystic mass in our patient in the lower pole of the left kidney the largest being $5.5 \mathrm{~cm}$ in diameter. There was no obvious vascular signaling in the septae between the cysts in Doppler US can and it was like type 3 hydatid cyst. However, there was a stone witrh a diameter of $1.5 \mathrm{~cm}$ in the middle calyx of left kidney and detorioration of the collection system. In CT; $104 \times 86$ mm-multicystic mass with multiple contrasted septae considered as cystic renal cell carcinoma was seen (Figure 1). No metastatic nodules or lymphadenopathy was detected in tomographic evaluation of thorax and abdomen.

In this case we did not perform preoperative biopsy due to well-contrast enhancement of the septae on tomographic views. In our opinion renal hydatid cyst and cystic renal cell carcinoma could be possible diagnoses and we studied serum Ecinococcus Granulosus IgG level to exclude hydatid cyst which is endemic for our country.

Nephron-sparing surgery is the suggested surgical treatment modality for a small renal mass. Even though surgery remains the standard of care for small renal tumors, cryoablation and radiofrequency ablation have emerged as minimally invasive treatment alternatives ${ }^{(7-12,13)}$. In our case, due to tumor size, similarity to cystic renal cell carcinoma and renal hydatid cyst, we decided to perform open total nephrectomy.

The resected left kidney measured $11.5 \mathrm{~cm} \times 9 \mathrm{~cm} \times 6$ $\mathrm{cm}$ without a solid component. A well-capsulated multilocular cyst mass was noted in the upper pole of the left kidney (Figure 2). Microscopically, wellcircumscribed, multilocular tumour with noncommunicating cysts lined by hobnail columnar or flattened epithelium was seen. The septa consisted of fibrous stroma, often with areas of cellular con-

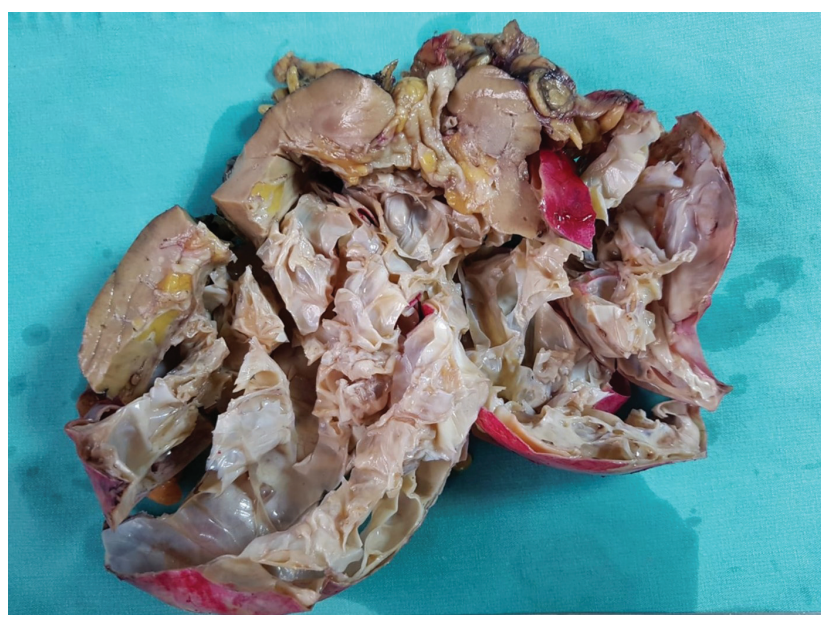

Figure 2.

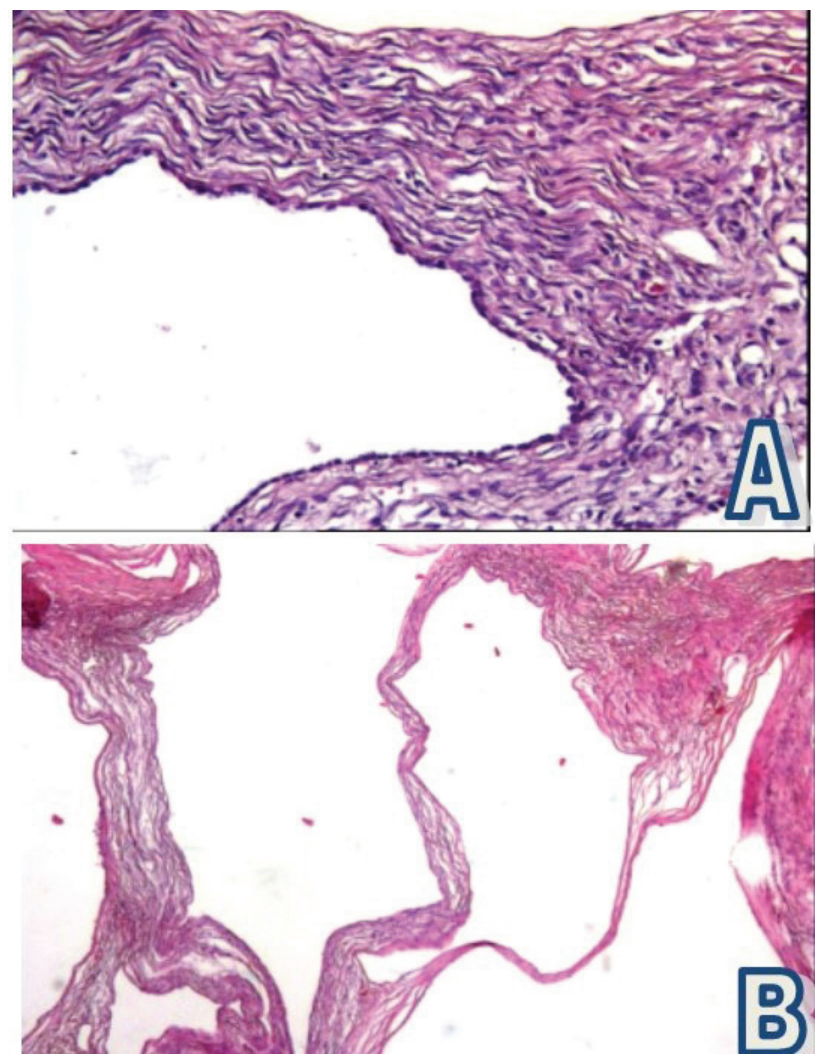

Figure 3. 
densation reminiscent of ovarian stroma (Figure 3). Immunohistochemically, tumor stained positively for cytokeratin (CK) 7, CK 19, CK AE1/AE3, vimentin, but it did not stain for estrogen receptor (ER), and progesterone receptor (PR). The final diagnosis of multilocular cystic nephroma was made.

Postoperative prognosis is excellent. Howeverup to now only three cases of recurrent bilateral cystic nephroma have been described in the literature. Other renal lesions may not be differentiated preoperatively from cystic nephroma and thus require surgical exploration. Long-term follow-up is recommended to rule out local recurrence ${ }^{(14)}$.

\section{Conflict of Interest: None. Informed Consent: None.}

\section{REFERENCES}

1. Stout TE, Au JK, Hicks JM, et al. A Case of bilateral cystic partially differentiated nephroblastoma vs cystic Wilms' tumor: Highlighting a diagnostic dilemma, Urology. 2016;92:106-9. [CrossRef]

2. Srigley JR, Delahunt B, Eble JN, et al. ISUP Renal Tumor Panel. The International Society of Urological Pathology (ISUP) Vancouver classification of renal neoplasia. Am J Surg Pathol. 2013;37:1469-89. [CrossRef]

3. Moch H, Cubilla AL, Humphrey PA, et al. The 2016 WHO Classification of tumours of the urinary system and male genital organs-part A: Renal, penile, and testicular tumours. Eur Urol. 2016;70(1):93-105. [CrossRef]

4. Singh S, Gupta R, Khurana N, et al. Multicystic nephroma report of two cases. Indian J Pathol Microbiol. 2004 Oct;47(4):520-3.

5. Grosse C, Sonnberger U, Grosse A, et al. Multilocular cystic nephroma: Atypical sonographic and computed tomographic findings. European Journal of Radiology Extra. 2006;58:13-6. [CrossRef]

6. Margulis V, Karam J, Matin S, et al. Benign renal tumours. Urology, Campbell-Walsh. Alan Wein, Louis Kavoussi, Alan Partin, Craig Peters. Elsevier, 2016. 1309.

7. Chang C-P, Li J-R, Yang C-S, et al. Multilocular cystic nephroma: A case report and review of the literature. Urological Science. 2014;25:109-111. [CrossRef]

8. Harisinghani MG, Maher MM, Gervais DA, et al. Incidence of malignancy in complex cystic renal masses (Bosniak category III): should imagingguidedbiopsy precede surgery? Am J Roentgenol. 2003;180:755-8. [CrossRef]

9. Banner MP, Pollack HM, Chatten J, et al. Multilocular renal cysts: radiologic-pathologic correlation. Am J Roentgenol. 1981;136:239-47. [CrossRef]

10. Betigeri AM, Subramanian B. Multilocular cystic nephroma: a surgical and radiological dilemma. Int J Curr Biol Med Sci. 2011;1:44-6.

11. Granja MF, O'Brien AT, Trujillo $S$ et al. Multilocular Cystic Nephroma: A Systematic Literature Review of the Radiologic and Clinical Findings. Am J Roentgenol. 2015;205(6):118893. [CrossRef]

12. Gettman MT, Segura JW. An unusual case of multilocular cystic nephroma with prominent renal pelvis involvement treated with nephron sparing techniques. J Urol. 1999;162:482. [CrossRef]

13. Hsiao HL, Wu WJ, Chang MY et al. Unusual case of multilocular cystic nephroma treated with nephron sparing technique: a case report. Kaohsiung J Med Sci. 2006;20:515-8. [CrossRef]

14. Bastian PJ, Kuhlmann R, Vogel J et al. Local recurrence of a unilateral cystic nephroma. Int J Urol. 2004;11:329-31. [CrossRef] 